\title{
PHYSICAL TRAINING ON GLYCEMIA AND OXIDATIVE STRESS IN TYPE 2 DIABETES: A SYSTEMATIC REVIEW
}

TREINAMENTO FÍSICO NA GLICEMIA E ESTRESSE OXIDATIVO EM DIABETES TIPO 2: REVISÃO SISTEMÁTICA

Systematic Review Article

ENTRENAMIENTO FÍSICO EN LA GLUCEMIA Y ESTRÉS OXIDATIVO EN DIABETES TIPO 2: ARTIGO DE REVISÃo SISTEMÁTICA REVISIÓN SISTEMÁTICA

Ediléa Monteiro de Oliveira ${ }^{1,2}$ (DD (Physiotherapist)

Andressa Karoline Pinto de Lima Ribeiro ${ }^{3}$ (D)

(Physiotherapist)

Dayse Danielle de Oliveira Silva',2 (DD (Physiotherapist)

Erica Feio Carneiro Nunes 1,2 (iD

(Physiotherapist)

Gisely Santiago Santos ${ }^{2}$ (D)

(Physiotherapist)

Katia Simone Kietzer ${ }^{4}$ (ID

(Physiotherapist )

Paulo de Tarso Camillo de Carvalho' 1 iD (Physiotherapist and Physical Education Professional)

1. Universidade Nove de Julho, Postgraduate Program in Rehabilitation Sciences, São Paulo, SP, Brazil.

2. Universidade do Estado do Pará, Belém, PA, Brazil.

3. Universidade do Estado do Pará, Multiprofessional Residency Program in Health - Oncology,

Belém, PA, Brazil.

4. Universidade do Estado do Pará, Morphophysiology Laboratory applied to Health, Belém, PA, Brazil.

\section{Correspondence:}

Ediléa Monteiro de Oliveira. Tv. Perebebuí, 2623, Marco, Belém, PA, Brazil. 66087-662. edileaoliveira@yahoo.com.br

\begin{abstract}
Introduction: Diabetes mellitus is accompanied by increased formation of reactive oxygen species (ROS) and decreased antioxidant capacity, leading to oxidative damage to cellular components. There is evidence to suggest that regular physical training positively changes oxidative homeostasis in the cells and tissues by lowering basal levels of oxidative damage, increasing resistance to oxidative stress. Objective: To verify the possible effects of aerobic physical training and resistance on glycemia and oxidative metabolism, and to determine whether there is any difference in outcomes resulting from different types of training in sedentary people with Type 2 Diabetes Mellitus (T2DM). Methods: A systematic review of controlled and randomized trials based on PRISMA. The databases LILACS, IBECS, Pubmed/MEDLINE, Cochrane Library, SciELO, PEDro, ScienceDirect and BIREME were searched, combining the descriptors type 2 diabetes mellitus, resistance training, aerobic exercise and oxidative stress in Portuguese, English and Spanish. The methodological quality of the papers was assessed by the PEDro scale. The data were read, analyzed, extracted and summarized. Results: Of the 1386 papers retrieved, only five met the inclusion criteria. The five selected papers, consisting of controlled and randomized clinical trials, were summarized. Conclusion: There have been many published studies reporting on exercises and diabetes. However, there is limitation when it comes to comparing their results. The variability of research methods and measurement instruments used makes it difficult to draw conclusions as to which physical training modality is most effective in reducing glycemic levels and oxidative stress in sedentary individuals with T2DM, considering that in each study analyzed in this review, the response to these variables is different. In future research, it would be important to standardize exercise modality, intensity, training time and evaluation parameters. Level of evidence l; Systematic review of RCTs (Randomized controlled trials).
\end{abstract}

Keywords: Diabetes mellitus, type 2; Oxidative stress; Blood glucose; Adults.

\section{RESUMO}

Introdução: A diabetes mellitus é acompanhada por um aumento da formação de espécies reativas de oxigênio (EROs) e diminuição da capacidade antioxidante, levando a danos oxidativos dos componentes celulares. Há evidência sugerindo que o treinamento físico regular altera positivamente a homeostase oxidativa nas células e tecidos, ao diminuir os níveis basais de danos oxidativos, aumentando a resistência ao estresse oxidativo. Objetivo: Verificar possiveis efeitos do treinamento físico aeróbio e de resistência sobre a glicemia e o metabolismo oxidativo e determinar se há diferença nos desfechos dos diferentes tipos de treinamento em indivíduos sedentários com Diabetes Mellitus tipo 2 (DM2). Métodos: Revisão sistemática de estudos controlados e randomizados baseada no PRISMA. Foram utilizadas as bases de dados LILACS, IBECS, Pubmed/MEDLINE, Cochrane Library, SciELO, PEDro, ScienceDirecte BIREME combinando os descritores diabetes mellitus tipo 2, treinamento de resistência, exercício aeróbio e estresse oxidativo em português, inglês e espanhol. A qualidade metodológica dos artigos foi avaliada pela escala PEDro. Realizou-se a leitura, análise, extração e síntese dos dados. Resultados: De 1386 artigos consultados, apenas cinco atenderam aos critérios de inclusão. Foi realizada a síntese dos cinco artigos selecionados, os quais consistem em ensaios clínicos controlados e randomizados. Conclusão: Há muitos estudos publicados relacionando exercícios e diabetes, entretanto, há limitação quando se pretende comparar seus resultados. A variabilidade dos métodos de pesquisa e dos instrumentos de medição utilizados tornam difícil concluir sobre qual modalidade de treinamento físico é mais eficaz em relação à redução dos níveis glicêmicos e do estresse oxidativo em individuos sedentários com DM2, considerando que, em cada estudo analisado nessa revisão, a resposta para essas variáveis é diferente. Em futuras pesquisas seria importante padronizar a modalidade de exercício, intensidade, o tempo de treinamento e os parâmetros avaliativos. Nível de evidência l; Revisão sistemática de ECRC (Estudos clínicos randomizados e controlados).

Descritores: Diabetes mellitus tipo 2; Estresse oxidativo; Glicemia; Adultos.

\section{RESUMEN}

Introducción: La diabetes mellitus es acompañada por un aumento de la formación de especies reactivas de oxígeno (ROS) y disminución de la capacidad antioxidante, llevando a daños oxidativos de los componentes celulares. Algunas evidencias sugieren que el entrenamiento físico regular altera positivamente la homeostasis 
oxidativa en las células y tejidos, al disminuir los niveles basales de daños oxidativos, aumentando la resistencia al estrés oxidativo. Objetivo: Verificar posibles efectos del entrenamiento físico aeróbico y de resistencia sobre la glucemia y el metabolismo oxidativo, y determinar si hay diferencia en los desenlaces de los diferentes tipos de entrenamiento en individuos sedentarios con Diabetes Mellitus tipo 2 (DM2). Métodos: Revisión sistemática de estudios controlados y aleatorizados, con base en el PRISMA. Se utilizaron las bases de datos LILACS, IBECS, Pubmed/MEDLINE, Cochrane Library, SCIELO, PEDro, ScienceDirect y BIREME combinando los descriptores diabetes mellitus tipo 2, entrenamiento de resistencia, ejercicio aeróbico y estrés oxidativo en portugués, inglés y español. La calidad metodológica de los artículos fue evaluada por la escala PEDro. Se procedió a la lectura, análisis, extracción y síntesis de los datos. Resultados: De 1386 artículos consultados, sólo cinco cumplieron los criterios de inclusión. Se hizo la síntesis de los cinco artículos seleccionados, que consisten en ensayos clínicos controlados y aleatorizados. Conclusión: Hay muchos estudios publicados relacionando ejercicios y diabetes, entretanto, existe limitación cuando se pretende comparar sus resultados. La variabilidad de los métodos de investigación y de los instrumentos de medición utilizados hacen que sea difícil concluir sobre qué modalidad de entrenamiento físico es más eficaz con relación a la reducción de los niveles glucémicos y del estrés oxidativo en individuos sedentarios con DM2, considerando que, en cada estudio analizado en esta revisión, la respuesta a estas variables es diferente. En futuras investigaciones sería importante estandarizar la modalidad de ejercicio, intensidad, el tiempo de entrenamiento y los parámetros evaluativos. Nivel de evidencia I; Revisión sistemática de ECAC (Estudios clínicos aleatorizados y controlados).

\section{Descriptores: Diabetes mellitus tipo 2; Estrés oxidativo; Glucemia; Adultos.}

\section{INTRODUCTION}

Diabetes mellitus type 2 (T2DM) is one of the most common metabolic diseases, with near to 200 million people worldwide being affected. It is a complex and heterogeneous group of metabolic conditions characterized by increased glucose blood levels. The three main defects leading to the onset of hyperglycemia in T2DM are increased hepatic glucose production, decreased insulin secretion and impaired action of insulin. ${ }^{1}$

Further to important metabolic changes, T2DM patients may also show complications such as cardiovascular diseases, coronary artery disease, neuropathy, nephropathy and retinopathy. There are evidences that these changes occur as a result of ROS generation leading to occurrence of oxidative stress in several tissues. ${ }^{2-5}$

It is noteworthy that diets rich in rapidly absorbable carbohydrates result in high levels of insulin and glycemia and fat deposition in the liver and muscle, increasing insulin resistance in these tissues, which in long term may lead to progressive failure of $\beta$-cells. Physical inactivity is also related to the increase of such resistance, contributing significantly to the increase on prevalence of T2DM worldwide. ${ }^{6}$

Regular physical training, therefore, seems to play an important role at prevention and treatment of diabetes, because it changes the oxidative homeostasis of cells and tissues by increasing the antioxidant capacity, reducing the damage caused by EROs, and inducing repair of damages in DNA. ${ }^{2-7}$

The purpose of this study is to verify possible effects of aerobic physical training and resistance on glycemia and oxidative metabolism, as well as to compare if there is a difference between the types of training in sedentary people with Type 2 Diabetes Mellitus.

\section{METHODS}

This systematic review was accredited under the number CRD42017060857 in the International Prospective Register of Systematic Comments - PROSPERO and elaborated based on the protocol "Preferred Reporting Items for Systematic Reviews and Meta-Analyses" (PRISMA, http://prisma-statement.org). ${ }^{8}$

\section{Inclusion Criteria}

The inclusion criteria were: Type 2 diabetes mellitus as searched disease, age between 40 and 70 years old, oxidative stress and glycemia as the main biochemical markers, aerobic and / or resistance physical training as intervention form, non-use of exogenous antioxidants or associated diet, controlled hypertension and dyslipidemia, randomized and controlled trials with humans, and scientific papers in English, Portuguese and Spanish. The databases LILACS, IBECS, Pubmed / MEDLINE, Cochrane Library, SciELO, PEDro, ScienceDirect and BIREME were used for the searching procedure.

\section{Searching strategy}

For the LILACS, Pubmed / MEDLINE, Cochrane Library, SciELO and BIREME databases, the descriptors type 2 diabetes mellitus, resistance training, aerobic exercise, oxidative stress found in the Health Sciences Descriptors (DECS) and in Medical Subject Headings (MESH) and respective synonyms thereof were crossed in the Portuguese, English and Spanish languages.

Each word was enclosed in parentheses and the Boolean operator OR was added therebetween. Parentheses were also placed at the beginning and end of each synonym group. The Boolean operator AND was used to join the groups of different descriptors. It is worth mentioning that all commas present between the search terms were removed.

For the PEDro, IBECS and ScienceDirect databases, a simple search with only the main terms and without the use of Boolean operators was performed.

\section{Studies selection and data extraction}

The selection process of the papers was made in four steps: identification, selection, eligibility and inclusion. The identification step included all papers found during the searching process. During this step the evaluation of the titles and abstracts of all identified papers was carried out, selecting those that met the eligibility criteria and excluding the remaining ones.

In the eligibility step, the papers were completely read to confirm that they could be included in the study using an Eligibility Form, which basically contained the inclusion criteria established, in order to register the exclusion reasons within such step. The inclusion step contains the papers that were used in the systematic review.

A consensus meeting was held between the authors to formulate the searching strategy to be used, to define the databases and inclusion 
criteria of the studies and the reference manager to be used in the research, as well as to establish the beginning searches dates and data collection within selected papers. During the selection process, the papers were grouped into a reference manager.

The information extracted from the selected papers was organized into a systematic review table containing the following information: first author, country where the study was carried out, sample age, study design, sample, interventions, measurement instruments and results.

\section{Methodological evaluation}

The methodological quality of each paper was analyzed based on the PEDro scale which is a specific database for studies investigating the efficacy of interventions in physical therapy. The majority of its criteria is based on the Delphi scale and focus on assisting PEDro database users regarding methodological quality of randomized clinical trials and also to assess the statistical description, i.e., whether the article contains minimum statistical information in order to interpret the results. ${ }^{9}$

PEDro Scale has a total of 11 evaluation criteria and includes two additional criteria that were not included in Delphi scale. The final score is given by the sum of the number of criteria that were classified as satisfactory (1 point) and unsatisfactory ( 0 point) between criteria 2 to 11. Criterion 1 is not considered for the final score because it is an item that verifies the external validity of the study. The final score can vary between 0 and 10 points. ${ }^{9,10,11}$

The authors used the scale independently and the disagreements between them were resolved through discussion and consensus. Papers that presented scores equal to or greater than five, in scale, were considered of high methodological quality. ${ }^{10,11}$

\section{RESULTS}

In total, 1386 articles were found. Of these 42 were duplicates, 662 were excluded because they are chapters of books, conference summaries or other type of publication not considered scientific article. There were 682 that were analyzed by title and abstract, 629 were excluded due to the fact that they did not use physical exercise as an intervention, did not have oxidative stress as a marker or did not have humans as a sample.

Out of the 53 remaining papers for full-text evaluation, 48 did not meet the inclusion criteria because they were not randomized trials, because they did not have one of the main markers, due to the use of an associated diet. At the end, five studies considered the inclusion criteria in full text. Figure 1 shows the flowchart containing the stages of the search and selection of articles.

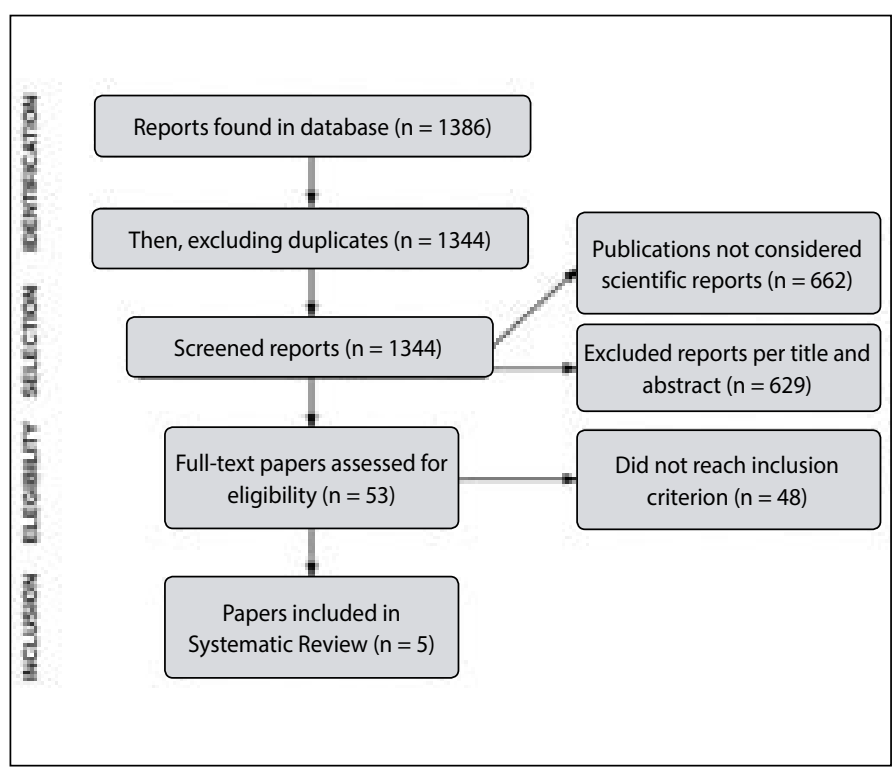

Figure 1. Flowchart of the search and selection of studies.
Table 1. Assessment of methodological quality by PEDro.

\begin{tabular}{c|c|c}
\hline Study & Quality assessment & PEDro score \\
\hline Mitranun et al. ${ }^{12}$ & $\begin{array}{c}\text { 1. Yes 2. Yes 3. No 4. Yes 5. No 6. No 7. } \\
\text { No 8. Yes 9. Yes 10. Yes 11. Yes }\end{array}$ & 6/10 \\
\hline Kurban et al. ${ }^{13}$ & $\begin{array}{r}\text { 1. No 2. Yes 3. No 4. Yes 5. No 6. No 7. } \\
\text { No 8. Yes 9. Yes 10. Yes 11. Yes }\end{array}$ & $6 / 10$ \\
\hline Vinetti et al. ${ }^{14}$ & $\begin{array}{r}\text { 1. Yes 2. Yes 3. No 4. Yes 5. No 6. No 7. } \\
\text { No 8. Yes 9. Yes 10. Yes 11. Yes }\end{array}$ & $6 / 10$ \\
\hline Oliveira et al. ${ }^{15}$ & $\begin{array}{r}\text { 1. Yes 2. Yes 3. No 4. Yes 5. No 6. No 7. } \\
\text { No 8. Yes 9. Yes 10. Yes 11. Yes }\end{array}$ & $6 / 10$ \\
\hline Mallard et al. ${ }^{16}$ & $\begin{array}{r}\text { 1. Yes 2. Yes 3. Yes 4. Yes 5. No 6. No 7. } \\
\text { No 8. Yes 9. Yes 10. Yes 11. Yes }\end{array}$ & 7/10
\end{tabular}

1: Eligibility criteria *; 2: Random allocation; 3: Secret allocation; 4: Baseline comparability; 5: Blind people; 6 : Blind therapists; 7: Blind Evaluators; 8: Adequate follow-up; 9: "intention to treat" analysis; 10: Comparisons between groups; 11: Point estimates and variability. * Criterion 1 does not contribute to the overall score."

The studies used were classified as having a high methodological quality according to an evaluation performed by PEDro Scale, as they obtained a grade above five as a result, in a graduation from 0 to 10, according to the filling of each item of the instrument, which is seen in Table 1.

It was performed the summary of the selected papers dealing with the effects of aerobic and / or resisted physical training on glycemia and oxidative stress of sedentary people with T2DM, four papers (80\%) used aerobic exercise as intervention in at least one of the groups, one paper (20\%) used resisted exercise in at least one of the groups, and two papers (40\%) used the combined exercise in one of the intervention groups. The intervention programs are detailed in Table 2.

All selected papers are publications in the English language. Then, the manuscripts were read, the data was collected, and its variables were synthesized. Data extracted from the studies are shown in Table 3.

The study by Mitranun et al. ${ }^{12}$ performed the comparison between continuous and aerobic interval exercise on glycemic control and macro and microvascular reactivity in patients with T2DM. The sample was divided into three groups: 15 in the sedentary group (SED), 14 in the continuous group (CON) and 14 in the interval group (INT). In this study, both continuous training and interval training were effective in improving glycemic control, lipid profiles, aerobic fitness and micro and macrovascular reactivity. However, only interval training achieved a significant reduction in oxidative stress, macro and microvascular reactivity, and glycated hemoglobin ( $\mathrm{HbA} 1 \mathrm{c})$. Both groups of physical training reduced fasting blood glucose and insulin resistance, according to HOMA (Homeostasis Model Assessment).

The study by Kurban et al. ${ }^{13}$ investigated the effect of regular aerobic physical exercise on total antioxidant capacity (TAS), total oxidant capacity (TOS), and levels of ischemia-modified albumin (IMA) in type 2 diabetic patients. The sample was divided into two groups: 30 patients in the exercise group and 30 in the non-exercise group. The results of such study demonstrated that 12 weeks of regular physical exercise with moderate intensity increases the TAS serum levels and prevents the IMA formation in people with T2DM, but does not cause changes in the TOS levels, showing that it is effective in prevention of oxidative stress.

The study by Vinetti et al. ${ }^{14}$ investigated the effect of supervised training for 12 months in people with T2DM regarding three main indicators: oxidative stress markers, cardiorespiratory fitness and cardiometabolic risk. The sample was divided into two groups: 10 patients in the exercise group, which underwent 12 months of aerobic training, resistance and flexibility; and 10 in control group, with no intervention beyond standard 
Table 2. Detailed intervention programs of studies.

\begin{tabular}{|c|c|c|c|c|}
\hline 1st Author & Modality & Duration & Frequency & Protocol \\
\hline Mitranun et al. ${ }^{12}$ & $\begin{array}{l}\text { Interval training interval (INT) } \\
\text { and continuous (CON) }\end{array}$ & 12 weeks & 3 times a week & $\begin{array}{l}\text { Exercise on treadmill, divided into } 3 \text { phases according } \\
\text { to consumption and } \mathrm{O} 2 \text { or caloric expenditure. }\end{array}$ \\
\hline Kurban et al. ${ }^{13}$ & Aerobic training & 12 weeks & 3 times / week for 50 min. & $\begin{array}{l}10^{\prime} \text { of heating, } 30^{\prime} \text { of moderate intensity } \\
\text { walk and } 10^{\prime} \text { reducing }\end{array}$ \\
\hline Vinetti et al. ${ }^{14}$ & $\begin{array}{l}\text { Aerobic training, resistance } \\
\text { and flexibility }\end{array}$ & 12 months & $\begin{array}{l}\text { Aerobic: in the first } 3 \text { months, } \\
\text { increased from } 15^{\prime} \text { to } 35^{\prime} ; \\
\text { Resisted: } 40^{\prime} \text { to } 50^{\prime}\end{array}$ & $\begin{array}{l}\text { Aerobic: ergometer cycle. Resisted: calisthenics exercises } \\
\text { and with weights at ankle, dumbbells and elastic bands. } \\
\text { Flexibility: stretches of superior and inferior limbs. }\end{array}$ \\
\hline Oliveira et al. ${ }^{15}$ & $\begin{array}{l}\text { Aerobic training (AT), resisted } \\
\text { (ST) and combined (CBT). }\end{array}$ & 12 weeks & 3 times / week for 60 min. & $\begin{array}{l}\text { Aerobic: cycling } \\
\text { Resisted: leg press, straight bench press, high pull, low } \\
\text { row, development, abdominal and flexor table. Combined: } \\
10^{\prime} \text { of cycling and } 2 \times 15 \text { for each resisted exercise }\end{array}$ \\
\hline Mallard et al. ${ }^{16}$ & $\begin{array}{l}\text { High-intensity interval training } \\
\text { (HIIT) and Traditional } \\
\text { moderate-intensity } \\
\text { continuous training (MICT) }\end{array}$ & 12 weeks & $\begin{array}{l}\text { HIIT - } 3 \text { times / week for } 40 \text { min } \\
\text { MICT - } 210 \text { minutes per } \\
\text { week of unsupervised } \\
\text { moderate intensity }(\sim 70 \% \text { HRmax })\end{array}$ & $\begin{array}{l}\text { HIIT: warming-up for } 10 \text { min at } 70 \% \text { of HRmax before } \\
\text { performing } 4 \times 4 \text { minute intervals at } 90-95 \% \text { of HRmax, } \\
\text { interspersed with } 3 \text { minutes active recovery at } 70 \% \text { of } \\
\text { HRmax and ending with a } 5 \text { min cool-down period } \\
\text { MICT: home based exercise sessions equivalent } \\
\text { to the current exercise guidelines as set by } \\
\text { the Norwegian Directorate of Health }\end{array}$ \\
\hline
\end{tabular}

Table 3. Summarization of study characteristics and results.

\begin{tabular}{|c|c|c|c|c|c|}
\hline 1st Author & Local / Year & Sample / Age & Design of the study & Measuring instruments & Results \\
\hline Mitranun et al. ${ }^{12}$ & $\begin{array}{l}\text { Bangkok, Thailand } \\
\text { (2013) }\end{array}$ & $\begin{array}{l}\text { Sample: } 43 ; 50 \\
\text { to } 70 \text { years }\end{array}$ & $\begin{array}{l}\text { Randomized controlled } \\
\text { clinical trial }\end{array}$ & $\begin{array}{l}\text { TBARS;GPX; SOD; HbA1c; fasting } \\
\text { glycemia; lipids; HOMA; vWF. }\end{array}$ & $\begin{array}{l}\text { CON and INT exercising programs } \\
\text { had beneficial effects on glycemic } \\
\text { control, physical fitness and micro } \\
\text { and macrovascular function, but } \\
\text { interval training was more effective. }\end{array}$ \\
\hline Kurban et al. ${ }^{13}$ & Konya, Turkey (2011) & $\begin{array}{c}\text { Sample: } 60 ; 40 \\
\text { to } 60 \text { years }\end{array}$ & $\begin{array}{l}\text { Randomized controlled } \\
\text { clinical trial }\end{array}$ & $\begin{array}{l}\text { Fasting glycemia; } \mathrm{Hb} 1 \mathrm{Ac} ; \\
\text { IMA, TOS and TAS. }\end{array}$ & $\begin{array}{l}\text { Chronic physical exercise prevents } \\
\text { increase of IMA levels, and is also } \\
\text { beneficial in preventing oxidative stress. }\end{array}$ \\
\hline Vinetti et al. ${ }^{14}$ & Montichiari, Italy (2015) & $\begin{array}{l}\text { Sample: } 20 ; 40 \\
\text { to } 70 \text { years }\end{array}$ & $\begin{array}{l}\text { Randomized controlled } \\
\text { clinical trial }\end{array}$ & $\begin{array}{l}\text { CPX; Fasting glycemia, } \\
\text { triglycerides, total cholesterol } \\
\text { and } \mathrm{HDL}, \mathrm{HbA1c} \text {; serum insulin; } \\
\text { HOMA-IR and ox-PAPC. }\end{array}$ & $\begin{array}{l}\text { One-year supervised training } \\
\text { improves insulin sensitivity and LDL } \\
\text { cholesterol blood levels, increases } \\
\text { cardiorespiratory fitness and leads to a } \\
\text { healthier body composition, resulting } \\
\text { in reduced systemic oxidative stress }\end{array}$ \\
\hline $\begin{array}{l}\text { de Oliveira } \\
\text { et al. }{ }^{15}\end{array}$ & $\begin{array}{l}\text { Minas Gerais, } \\
\text { Brazil (2012). }\end{array}$ & $\begin{array}{c}\text { Sample: } 43 ; 40 \\
\text { to } 70 \text { years }\end{array}$ & $\begin{array}{l}\text { Controlled and } \\
\text { randomized clinical trial }\end{array}$ & $\begin{array}{l}\text { Fasting glycemia; Postprandial } \\
\text { glucose; Hemogram; CAT; SOD; } \\
\text { GSH-Px; TBARS and NO Levels }\end{array}$ & $\begin{array}{l}\text { In aerobic training the antioxidant } \\
\text { enzymes increased the activity of } \\
\text { CAT and SOD, and the bioavailability } \\
\text { of NO, offering protection against } \\
\text { oxidative stress. Improvements } \\
\text { in metabolic parameters were } \\
\text { seen only in the ST group. }\end{array}$ \\
\hline Mallard et al. ${ }^{16}$ & $\begin{array}{c}\text { Queensland, } \\
\text { Australia (2017) }\end{array}$ & $\begin{array}{l}\text { Sample: } 36 ; 44 \\
\text { to } 65 \text { years }\end{array}$ & $\begin{array}{l}\text { Randomized controlled } \\
\text { clinical trial }\end{array}$ & $\begin{array}{c}\text { HbA1c; Triglycerides;HDL;LDL;Cho } \\
\text { lesterol;HOMA-IR; F2-isoprostanes; } \\
\text { Glutathione peroxidase activity;Total } \\
\text { antioxidant capacity;Protein } \\
\text { carbonyls;Interleukin-10;Interleukin- } \\
\text { 6;Interleukin-8; TNF-a }\end{array}$ & $\begin{array}{l}\text { MICT and HIIT had no effect on oxidative } \\
\text { stress and inflammation levels in this } \\
\text { particular study. The HIIT intervention was } \\
\text { able to maintain TAC in the 12-month } \\
\text { follow-up period whereas MICT was not. }\end{array}$ \\
\hline
\end{tabular}


medical care. There was also a third group with 10 healthy people who received neither intervention nor follow up.

The data from Vinetti et al. ${ }^{14}$ study confirmed that people with T2DM present a more oxidizing environment than healthy people, and a significant decrease in plasma concentrations of phospholipid 1-palmitoyl-2-arachidonyl-sn-glycero-3-phosphorylcholine (OxPAPC) in exercise group indicates that specific exercising program had a role in improving oxidative stress. However, there was no significant reduction of $\mathrm{HbA1c}$, despite a significant improvement in HOMA-IR, but the mean $\mathrm{HbA} 1 \mathrm{c}$ baseline had a value of $7.0 \%$, which suggests optimal diabetes control. The exercise performed in this study also provided an improvement in cardiorespiratory fitness, demonstrated by the improvement of the maximum Oxygen Volume (VO2max), and reduction of cardiometabolic risk factors.

The Oliveira et al. ${ }^{15}$ study investigated the influence of three physical exercising programs (aerobic, resisted and combined training) on oxidative stress markers, antioxidant capacity and metabolic parameters in people with T2DM for 12 weeks. The sample was divided into four groups: 11 in the aerobic group (AT), 10 in the resisted group (ST), 10 in the combined group (CBT) and 12 in the sedentary group (NT). In AT group, antioxidant enzymes increased the activity of catalase (CAT) and superoxide dismutase (SOD) and increased the bioavailability of nitric oxide (NO), reducing oxidative stress. However, there was no change in the glutathione peroxidase (GSH- Px) activity in any of the groups after the intervention. Significant changes in metabolic control parameters, such as HbA1c, fasting glycemia, triglycerides and high density lipoprotein cholesterol was shown only in the ST group. In addition, there was no additional benefit in anthropometric or metabolic parameters, except for improvement in $\mathrm{VO}_{2}$ peak in the AT group.

In the study by Mallard et al., ${ }^{16} 36$ participants with T2DM were allocated into two groups in a randomized, HIIT (High Intensity Interval Training) or MICT (Moderate Intensity Continuous Training) group, through of a parallel design. Participants completed the first phase of 12 weeks of specific intensity physical training with a combination of supervised and home training. In the second phase there was a follow-up of the training of 40 weeks at home, without supervision, oriented to maintain the same intensity. Adherence to this phase was monitored by emails and phone calls. There were no significant differences between redox homeostasis and inflammatory biomarkers at baseline, 12 weeks or one year.

\section{DISCUSSION}

No papers were found according to the criteria adopted by this review that deal specifically with a single type of physical training, since all of them contained other training or were associated to compare the effects between the groups.

The most used intervention in at least one of the groups was aerobic training, three times a week, for 12 weeks. Studies using similar parameters, with frequency of three to four times / week and with sessions lasting from 30 to 60 minutes demonstrated a beneficial effect of regular exercise on carbohydrate metabolism and insulin sensitivity. ${ }^{17} 50 \%$ of the studies used HOMA (Homeostatic Model Assessment) ${ }^{12,14}$ to check for insulin resistance, and all studies used $\mathrm{HbA} 1 \mathrm{c}$ and fasting glucose to assess the changes in glycemic levels.

The Monteiro et al. ${ }^{18}$ study demonstrated that 13 weeks of aerobic training (walking) lasting 50 minutes, for three times a week, is able to promote significant reductions in blood glucose and blood pressure in elderly diabetics. In another clinical randomized study ${ }^{19}$ with 75 adults with type 2 diabetes, mean age of 59 years, the authors concluded that glycemic control of type 2 diabetes patients such as fasting glycemia, triglycerides, total cholesterol and body mass index (BMI) showed improvements after 12 weeks of aerobic exercise (walking) with frequency of three days per week and lasting 60 minutes each session.

The study by Oliveira et al. ${ }^{15}$ used three protocols that were aerobic, resistance and combined training, and found that only in the resistance training group there were significant changes in metabolic control parameters, such as HbA1c, FPG, triglycerides and high-density lipoprotein cholesterol, and the aerobic training group presented a better response to oxidative stress.

This reduction was seen in the work of Nogueira ${ }^{20}$ which compared aerobic training and resistance training with weight, in an elderly and diabetic patient, with greater efficiency in glycemic control and resistance training. Robert-Pires and Carvalho ${ }^{21}$ also observed a significant acute reduction of glycemia, after using a protocol consisting of resistance exercise in circuit, with moderate intensity and submaximal repetitions.

In Sousa et al. ${ }^{22}$ study with male diabetic patients, in only one session of resisted exercise a significant reduction of glycemia was seen, thus, the resisted exercise in high intensity was shown to be beneficial to glycemic control and in the improvement of insulin resistance in type 2 diabetics. It is believed that resistance exercises, besides promoting the improvement in stimulation of fat metabolism, also promotes the increase of basal metabolic rate, since they provide the increase of the muscular mass, which in turn will increases glucose consumption, thus contributing to a better glycemic control. ${ }^{23}$

In this systematic review, combined training between aerobic and resisted exercise was also intervention in at least one group, but no improvement in metabolic control parameters, such as $\mathrm{HbA} 1 \mathrm{c}$, was seen. Only one study found improvement in HOMA-IR parameters.

This contradicts other studies, such as Church et al., ${ }^{24}$ in which 262 people with randomly arranged T2DM performed combined training, these people achieved a statistically significant reduction when compared to people of control, aerobic and resisted groups related to $\mathrm{HbA} 1 \mathrm{C}$ levels. Segerström et al. ${ }^{25}$ also reported a significant increase in insulin sensitivity and a decrease in $\mathrm{HbA} 1 \mathrm{c}$ after performing a combined training with diabetic women for six months. It was concluded that insulin sensitivity is directly related to exercise intensity, whereas $\mathrm{HbA} 1 \mathrm{c}$ is mainly related to training volume. The research emphasized training volume rather than intensity, as evidenced by the more significant reduction of $\mathrm{HbA} 1 \mathrm{c}$ in the combined training group.

The fact that the selected papers for this review have found results different from the others may be associated then, according to Brun et al. $^{26}$ and Krousel et al., ${ }^{27}$ to the use of low intensity interventions, low volume or low compliance to intervention being the study of Mallard et al., ${ }^{16}$ the only one to use training of moderate and intense intensities. These authors report that both MICT (Moderate Intensity Continuous Training) and HIIT (High Intensity Interval Training) had no effect on oxidative stress and inflammatory levels in individuals with T2DM over the 12 weeks of intervention with one year follow-up. However, HIIT was able to maintain TAC (Total Antioxidant Capacity) during the 12 months of follow-up, while the MICT did not. The inability to obtain a positive effect on the homeostasis biomarkers of inflammation and redox over the 12-week intervention period contrasts with the current literature suggesting that exercise in individuals with DT2DM is beneficial for redox homeostasis and inflammatory health.

According to Mitranun et al., ${ }^{12}$ both continuous aerobic training and interval training were effective in improving glycemic control $(\mathrm{HbA} 1 \mathrm{c}$, fasting glycemia and insulin resistance-HOMA), but the interval exercise presented a significant reduction of $\mathrm{HbA} 1 \mathrm{c}$. The Tjonna et al. ${ }^{28}$ study 
corroborates with Mitranun et al. ${ }^{12}$ because it reports that the interval aerobic training presents effective control in fasting glycemia and $\mathrm{HbA} 1 \mathrm{c}$, increases insulin sensitivity (HOMA) and associates the intensity of the exercise with a positive change of mentioned parameters.

Vinetti et al., ${ }_{1}^{14}$ studied a combined training, report a reduction in insulin resistance by means of $\mathrm{HOMA}-\mathrm{IR}$, fasting blood glucose, and $\mathrm{HbA1C}$, the latter not being a statistically significant decrease. The Oliveira et al. ${ }^{15}$ study also reported a significant decrease in $\mathrm{HbA1c}$ levels and fasting glycemia, but only in the group that performed a resistance training. A study performed with combined training (aerobic associated with resistance training) and in an isolated way (aerobic or resisted) showed that combined exercise has greater effects on glycemic control. These effects are more effective among people with poor basal glycemic control, therefore, people with low glycemic control can perform either aerobic or resisted or combined exercises. ${ }^{29}$

For Praet and Van Loon ${ }^{30}$ there are apparent differences in the long-term adaptive response to aerobic and resisted training. Prolonged aerobic training has been shown to improve insulin sensitivity in young, elderly, and/or insulin resistant people. Interventions with long term resistance exercises have also been reported to improve glucose tolerance and insulin sensitivity. Thus, both types of exercise are useful for therapeutic use in an insulin resistant status.

The effect of physical activity on tissue sensitivity to insulin is due to the greater capillarization of muscle fibers and better mitochondrial function, which occurs 24 to 72 hours after an exercise session. In addition, blood glucose uptake into muscles by non-insulin-dependent mechanisms may increase, leading to improved glycemic regulation observed by lower basal and postprandial insulin concentrations, as well as by the reduction of $\mathrm{HbA} 1 \mathrm{c}^{31}$

Oxidative stress was the parameter that most demonstrated changes with the proposed physical training programs. Each author used different parameters for marking oxidative metabolism and antioxidant capacity, however, most have shown that aerobic exercise provides an increase or maintenance of antioxidant indicators, thus, attenuating the oxidative stress in T2DM patients.

The search for Villa-Caballero et al. ${ }^{32}$ identified significant changes in the oxidative and hemodynamic stress profile of T2DM patients who performed regular aerobic physical activity for at least 180 minutes per week, showing lower levels of thiobarbituric acid (TBARS) compared to their sedentary counterparts, showing a possible protector effect of regular exercise against oxidative stress in T2DM, and confirming what was found in the analyzed papers.

According to Kostic et al., ${ }^{33}$ high levels of oxidized low-density lipoprotein (OxLDL), SOD and GSH-Px are associated with acute exercise in patients with T2DM, which may be a compensatory mechanism against damage caused by ROS. It is believed that physical training induces an increase in muscle activity and liver antioxidant enzymes and reduces oxidative stress.

Several studies infer and corroborate with those reviewed by such review that the training may cause adaptive responses in the endogenous antioxidants and reduce oxidation and plasma lipid peroxidation, and may influence in redox homeostasis and, consequently, redox-dependent adaptation processes. ${ }^{2}$

\section{CONCLUSION}

There are many recently published articles on exercise and diabetes. However, there is a limitation when comparing the results obtained by these surveys. The variability of research methods and measurement instruments makes it difficult to conclude about the effects of physical training on glycemic control and on the level of oxidative stress in individuals with T2DM.

Further studies need to be carried out regarding the influence of aerobic physical training and, mainly, on resistance exercises in glycemic control and oxidative stress levels in individuals with T2DM.

We believe that more important than carrying out new research would be to standardize the study method, such as the exercise modality, intensity, training time, evaluative parameters, so that the works can be compared, and the results obtained may contribute to other investigations.

Unfortunately, the above limitations have prevented us from concluding through this systematic review, which physical training may improve glycemic and oxidative stress levels in sedentary individuals with T2DM.

\section{ACKNOWLEDGEMENTS}

This work was supported by National Council for Scientific and Technological- CNPQ (grant numbers 434414/2018-2 and 307518/2018-3).

$\overline{\text { All authors declare no potential conflict of interest related to this article }}$

AUTHORS' CONTRIBUTIONS: Each author made significant individual contributions to this manuscript. EMO (0000-0002-5563--5447)*: substantial contribution to the conception and design of the work, drafting of the work, and analysis and interpretation of data for the work; DDOS (0000-0001-8400-1104)*: critical review of the intellectual content and approval of the final version of the manuscript for publication; EFCN (0000-0002-1274-4686)*: critical review of the intellectual content and approval of the final version of the manuscript for publication; AKPLR (0000-0002-7981-938X)*: substantial contribution to the conception and design of the work, drafting of the work, and analysis and interpretation of data for the work; GSS (0000-0001-6143-3588)*: substantial contribution to the conception and design of the work, drafting of the work, and analysis and interpretation of data for the work; KSK (0000-0001-6992-3557)*: critical review of the intellectual content and approval of the final version of the manuscript for publication; PTCC (0000-0001-9624-4103)*: critical review of the intellectual content and approval of the final version of the manuscript for publication. *ORCID (Open Researcher and Contributor ID).

\section{REFERENCES}

1. Teixeira-Lemos E, Nunes $S$, Teixeira F, Reis F. Regular physical exercise training assists in preventing type 2 diabetes development: focus on its antioxidant and anti-inflammatory properties. Cardiovasc Diabetol. 2011;10:12.

2. Pittaluga M, Sgadari A, Dimauro I, Tavazzi B, Parisi P, Caporossi D. Physical exercise and redox balance in type 2 diabetics: Effects of moderate training on biomarkers of oxidative stress and DNA damage evaluated through comet assay. Oxid Med and Cell Longev. 2015; 2015:981242.

3. Golbidi S, Badran M, Laher I. Antioxidant and anti-inflammatory effects of exercise in diabetic patients. Exp Diabetes Res. 2012;2012:941868.

4. Leelayuwat $\mathrm{N}$, Tunkumnerdthai O, Donsom M, Punyaek N, Manimanakorn A, Kukongviriyapan U, et al. An alternative exercise and its beneficial effects on glycaemic control and oxidative stress in subjects with type 2 diabetes. Diabetes Res Clin Pract. 2008;82(2):e5-8.

5. Asmat U, Abad K, Ismail K. Diabetes mellitus and oxidative stress - A concise review. Saudi Pharm J. 2016;24(5):547-53.

6. Cornell S. Continual evolution of type 2 diabetes: an update on pathophysiology and emerging treatment options. Ther Clin Risk Manag. 2015;11:621-32.

7. Lemos ET, Oliveira J, Pinheiro JP, Reis F. Regular physical exercise as a strategy to improve antioxidant and
anti-Inflammatory status: benefits in type 2 diabetes mellitus. Oxid Med Cell Longev. 2012;2012:741545.

8. Galvão TF, Pansani TS, Harrad D. Principais itens para relatar revisões sistemáticas e meta-análises: A recomendação PRISMA. Epidemiol Serv Saúde. 2015;24(2): 335-42.

9. Shiwa SR, Costa LO, Moser AD, Aguiar IC, Oliveira LV. PEDro a base de dados de evidências em fisioterapia. Rev Fisiot Mov. 2011;24(3):523-33.

10. Cipolat S, Pereira BB, Ferreira FV. Fisioterapia em Pacientes com Leucemia: Revisão Sistemática. Rev Bras Cancerol. 2011;57(2):229-36.

11. Physiotherapy evidence database [Internet]. Escala PEDro [acesso em 2016 out 19]. Disponível em: http://www.pedro.org.au/portuguese/downloads/pedro-scale

12. Mitranun W, Deerochanawong C, Tanaka H, Suksom D. Continuous vs interval training on glycemic control and macro- and microvascular reactivity in type 2 diabetic patients. Scand J Med Sci Sports. 2014;24(2):e69-76.

13. Kurban S, Mehmetoglu I, Yerlikaya HF, Gonen S, Erdem S. Effect of chronic regular exercise on serum ischemia-modified albumin levels and oxidative stress in type 2 diabetes mellitus. Endocr Res. 2011;36(3):116-123 
14. Vinetti G, Mozzini C, Desenzani P, Boni E, Bulla L, Lorenzetti I, et al. Supervised exercise training reduces oxidative stress and cardiometabolic risk in adults with type 2 diabetes: a randomized controlled trial. Sci Rep. 2015;5(9238).

15. Oliveira VN, Bessa A, Jorge ML, Oliveira RJ, de Mello MT, De Agostini GG, et al. The effect of different training programs on antioxidant status, oxidative stress, and metabolic control in type 2 diabetes. Appl Physiol Nutr Metab. 2012;37(2):334-44.

16. Mallard AR, Hollekim-Strand SM, Coombes JS, Ingul CB. Exercise intensity, redox homeostasis and inflammation in type 2 diabetes mellitus. J Sci Med Sport. 2017;20(10):893-8.

17. American College of Sports Medicine, American Diabetes Association. Diabetes mellitus e exercício. Rev Bras Med Esporte. 2000;6(1):16-22.

18. Monteiro LZ, Fiani CR, Freitas MC, Zanetti ML, Foss MC. Redução da pressão arterial, do IMC e da glicose após treinamento aeróbico em idosas com diabete tipo 2. Arq Bras Cardiol. 2010;95(5):563-70.

19. Goldhaber-Fiebert JD, Goldhaber-Fiebert SN, Tristán ML, Nathan DM. Randomized controlled communitybased nutrition and exercise intervention improves glycemia and cardiovascular risk factors in type 2 diabetic patients in rural Costa Rica. Diabetes Care. 2003;26(1):24-9.

20. Nogueira AC. O exercício resistido com peso promove uma maior eficiência na queda da glicemia em pacientes com diabetes quando comparado com exercício aeróbico. Rev Bras Presc Fisiol Exercicio. 2010;4(22):342-51.

21. Robert-Pires CM, Carvalho RS. Exercício resistido em circuito promove redução aguda da glicemia em diabéticos não-insulino-dependentes. Rev Bras Presc Fisiol Exercicio. 2012;6(34):336-341.

22. Sousa RA, Santos NV, Pardono E. Redução da glicemia através do exercício resistido de alta intensidade em indivíduos com diabetes mellitus tipo 2. Rev Bras Presc Fisiol Exercicio. 2014;8(50):871-6.

23. Zabaglia R, Assumpção CO, Urtado CB, Souza TM. Efeito dos exercícios resistidos em portadores de diabetes mellitus. Rev Bras Presc Fisiol Exercicio. 2009;3(18):547-558.

24. Church TS, Blair SN, Cocreham S, Johannsen N, Johnson W, Kramer K, et al. Effects of aerobic and resistance training on hemoglobin A1c levels in patients with type 2 diabetes: a randomized controlled trial. JAMA. 2010;304(20):2253-62.

25. Segerström AB, Glans F, Eriksson KF, Holmbäck AM, Groop L, Thorsson O, et al. Impact of exercise intensity and duration on insulin sensitivity in women with T2D. Eur J Intern Med. 2010;21 (5):404-8.

26. Brun JF, Bordenave S, Mercier J, Jaussent A, Picot MC, Préfaut C. Cost-sparing effect of twice-weekly targeted endurance training in type 2 diabetics: a one-year controlled randomized trial. Diabetes Metab. 2008;34(3):258-65.

27. Krousel-Wood MA, Berger L, Jiang X, Blonde L, Myers L, Webber L. Does home-based exercise improve body mass index in patients with type 2 diabetes? Results of a feasibility trial. Diabetes Res Clin Pract. 2008;79(2):230-6

28. Tjonna AE, Lee SJ, Rognmo O, Stolen TO, Bye A, Haram PM, et al. Aerobic interval training versus continuous moderate exercise as a treatment for the metabolic syndrome: a pilot study. Circulation. 2008;1 8(4):346-54.

29. Sigal RJ, Kenny GP, Boulé NG, Wells GA, Prud'homme D, Fortier M, et al. Effects of aerobic training, resistance training, or both on glycemic control in type 2 diabetes: a randomized trial. Ann Intern Med. 2007;147(6):357-69

30. Praet SF, van Loon LJ. Exercise therapy in Type 2 diabetes. Acta Diabetol. 2009;46(4):263-78.

31. Sociedade Brasileira de Diabetes. Diretrizes da Sociedade Brasileira de Diabetes 2015-2016. [acesso em 2016 out 19] Disponível em: http://www.diabetes.org.br/sbdonline/images/docs/DIRETRIZES-SBD-2015-2016.pdf

32. Villa-Caballero L, Nava-Ocampo AA, Frati-Munari AC, Rodríguez de León SM, Becerra-Pérez AR, Ceja RM, et al. Hemodynamic and oxidative stress profile after exercise in type 2 diabetes. Diabetes Res Clin Pract. 2007;75(3):285-91.

33. Kostić N, Caparević Z, Marina D, llić S, Radojković J, Cosić Z, et al. Clinical evaluation of oxidative stress in patients with diabetes mellitus type II - impact of acute exercise. Vojnosanit Pregl. 2009;66(6):459-64 